\title{
Pre-mining water quality prediction from non-weathered sulphide ores along the Ashanti metallogenic belt in Ghana using Acid-Base accounting procedure
}

\author{
Gordon Foli ${ }^{1 *}$, Ohene B. Apea ${ }^{2}$ and Chiri G. Amedjoe ${ }^{3}$ \\ ${ }^{1}$ Department of Geological Engineering, College of Engineering \\ Kwame Nkrumah University of Science and Technology, Kumasi, Ghana \\ ${ }^{2}$ Department of Applied Chemistry and Biochemistry \\ University for Development Studies, Navrongo Campus, Navrongo, Ghana \\ ${ }^{3}$ Department of Earth and Environmental Sciences \\ University for Development Studies, Navrongo Campus, Navrongo, Ghana \\ ${ }^{*}$ Corresponding Author: gordon.foli01@gmail.com
}

\begin{abstract}
The prediction of pre-mining water quality from non-weathered sulphide ores using the Acid-Base accounting (ABA) procedure was studied at the Anglogold-Ashanti, Obuasi mine and located on the Ashanti metallogenic belt in Ghana. The purpose of the study was to establish database for use during preliminary mining project evaluation, mining project permitting, and tailings waste management planning and implementation. Total Sulphur (TS) was determined by hightemperature furnace combustion using the LECO sulphur analyzer, while carbonate was determined by gravimetric method. Average TS \% and Neutralization Potential (NP) due to calcium carbonate were $1.46 \%$ and $4.34 \mathrm{~kg} \mathrm{CaCO}_{3} /$ ton respectively. The average TS\% multiplied by the constant 31.25 yielded Maximum Potential Acidity (MPA) value of $45.63 \mathrm{~kg} \mathrm{CaCO}_{3}$ /ton. Also, Net Neutralization Potential (NNP), defined by NNP=NP-MPA, yielded the value $-41.29 \mathrm{~kg}$ $\mathrm{CaCO}_{3}$ /ton and NP: MPA ratio of 0.095 . Multiple regression statistics on NP and MPA gave Rsquare value as 0.0005 and indicated a poor predictive neutralization model. From the NNP and NP: MPA values, it was concluded that the non-weathered sulphide ores at the AnglogoldAshanti, Obuasi mine are likely to generate high acidic waters. Adequate alkaline amendment is therefore required during ore treatment.
\end{abstract}

Keywords: Acid-Base accounting, Neutralisation Potential, Maximum Potential Acidity, Ashanti metallurgenic belt, Acid Mine Drainage.

\section{INTRODUCTION}

Mining activity is one of the many causes of pollution of water resources and often creates imbalanced contaminant conditions between the land and water regimes in both quantitative and qualitative ways. Among the various causes of qualitative pollution is acid mine drainage (AMD). Acid mine drainage primarily results from the oxidation of exposed sulphide minerals in the presence of water and atmospheric oxygen (Saharan et al. 1995). Acid mine drainage is considered as one of the most significant and the largest environmental problems facing the mining industry. Once AMD process sets off, it becomes very difficult to control (da Rosa and Lyon, 1997).
The numerous methods of the suphide ore pretreatment and processing practices often increase the surface area of the material, thereby increasing the oxidative processes that promote AMD. As a management tool, companies have been mandated by environmental regulatory groups such as the environmental protection agency (EPA) to conduct pre-mining water quality investigations that will succinctly provide evidence for pro-active remediation plans to avert any possible post-mining water quality problems (Runkel et al. 2007). Common pro-active remediation plans include alkaline amendment schemes, ostensibly designed to inhibit the oxidation of pyritic spoils and possible acid generation (Rich and Hurchison 1990; Brady et al. 1990; Perry and Brady 1995; Rose et al. 1995). 
Hamric et al. (2001) indicated that during the prediction of pre-mining water quality, nearly all alkaline amendment schemes rely on Acid-Base Accounting (ABA). The ABA test procedure determines the acid-producing and acid-neutralizing potentials of a test material (Sobek et al. 1978). AcidBase Accounting is a highly projected and favoured geochemical characterisation method with a relatively short turn-around time; the procedure is very cost effective as compared with other methods (US EPA 1994; Maest et al. 2005). By reason of the above qualities, $A B A$ is often recommended for use at the exploration phase of mining projects for early decision making (McKenna et al. 2009).

In general, AMD predictions for water quality are often associated with uncertainties due to the combination of some complex variables such as inaccurate hydrological and geochemical characterization (Skousen et al 2002; Kuipers et al. 2006; Jenning et al. 2008). That notwithstanding, acurate prediction is recognized by both industry and government as a critical requirement for mines permitting and long-term operation (Maest et al. 2005; Skousen and Ziemkiewicz 1996; MEND 2001).

Interestingly however, notable errors such as outlined by Hamric et al. (2001); Rymer et al. (1991); Wiram and Nauman (1995) are peculiar to coal deposits (US EPA 1994). Contrary to the above observation therefore, the current study which is in a hardrock environment is anticipated to have different geological and geochemical characteristics as compared with those of coal mine deposits. For example, with unique applicable mining methods and grade control practices as described by Hamrin (1986), it is envisaged that the study environment will offer geological and geochemical characteristics that will influence processes differently.

In essence, adequate minimization of ore loss due to good grade control practices will generate mill tailings that will serve as the most common source of acid generation. Gautama and Hartaji (2004) indicated that depending upon the evaluation methodologies, particle size variability may result in overestimation of MPA. According to writers such as Stromberg and Banwart (1999); White et al. (1999); Scharer et al. (2000) and Kempton (2002), the finer the particle size the better the quality of the ABA test results. This therefore implies that mill tailings, which is made up of clay/silt-sized particles will definitely offer a good enough medium for mine planning and acid neutralization programs involving carbonates.
A challenge with most emerging projects is inadequate information on predictive data; and this often results in speculative statements to justify AMD issues for purposes of mine permitting. The end result will therefore be huge disparities between pre-mining prediction and post mining verifications. Also from the fact that AMD, once triggered becomes very difficult to handle, it is very necessary that the process is completely prevented from starting altogether through effective pre-mining water quality prediction. This is very important because, alkaline amendment programme which is a common solution for controlling or remediating AMD in industry is noted to be cost intensive when used reactively (Singh and Singh 1992; Saharan et al. 1995) but on the contrary, the programme is noted to be cost effective when used proactively (Hamric et al. 2001).

The Ashanti metallogenic belt has the potential for hosting many new underground mines, due to the vastly exhausted surface resources along the belt in the 1990s. The 1990s witnessed a mining boom that led to the setting up many open pit mines, in response to the Ghanaian Mining Industry Policy Initiative of 1983 to promote investment in the sector (Akabzaa, 2000; Sanderson, 2009). Due to cost constrains and low capital base of many emerging companies, an initial data base availability for use in the preliminary planning and permitting has become very necessary. This research at the AnglogoldAshanti, Obuasi mine, therefore determined the acid generation and neutralisation potentials of sulphide ores for the prediction of the pre-mining water quality likely to be associated with mill tailings at mine sites. Findings could also be useful for front end planning for the management of waste water discharges from tailing dam sites.

Geological Setting: The area is underlain by Paleoproterozoic Birimian and Takwaian rocks. In Ghana, the Birimian is classified into a two-fold lithostratigraphic systems consisting of metavolcanic and metasedimetary groups with an overlying younger arenaceous and clastic Tarkwaian group. The rocks of the metavolcanic group are dominated by low grade tholeiitic basalts with intercalated pyroclastic rocks as well as minor andesitic and felsic flows and chemical sediments (Kesse 1985).

The metasedimentary rocks comprise low grade metamorphosed volcaniclastics, wackes and argillites, considered as partly contemporaneous with the volcanic group. The Tarkwaian group comprises polymictic as well as quartz pebble conglomerates, sandstones and minor argillites, siltstones and tuffs 
(Kesse 1985). The Birimian rocks are intruded by hornblende-rich granitoids known as the 'Dixcove' or 'belt' type that are closely associated with the volcanic rocks and; and mica-rich granitoids referred to as 'Cape Coast' or 'basin' type which tend to border the volcanic belt and are in the metasediment units, (Leube et al. 1990; Taylor et al. 1992; Hirdes et al. 1992).

Gold in the Ashanti belt occur as quartz reefs in the metasediments or vein/lode type deposits near or at the contact between the metasediments and the metavolcanics (Kesse 1985). The metavolcanic and metasedimetary groups are separated by a major shear zone, which at times contain visible calcite minerals associated with quartz bodies (Kesse 1985; Leube et al. 1990). Primary gold ores are dominated by arsenopyrite and pyrite with minor quartz with graphitic schist bands (Osae et al. 1995). The metavolcanic and metasedimentary rocks are also occasionally ankerite spotted.

\section{MATERIALS AND METHODS}

Study area and sampling procedure: The study area is located on the Ashanti gold belt in southern Ghana, and between latitude $5.35 \mathrm{~N}$ and $5.65 \mathrm{~N}$ and longitude $6.35 \mathrm{~N}$ and $6.90 \mathrm{~N}$ (Fig 1).

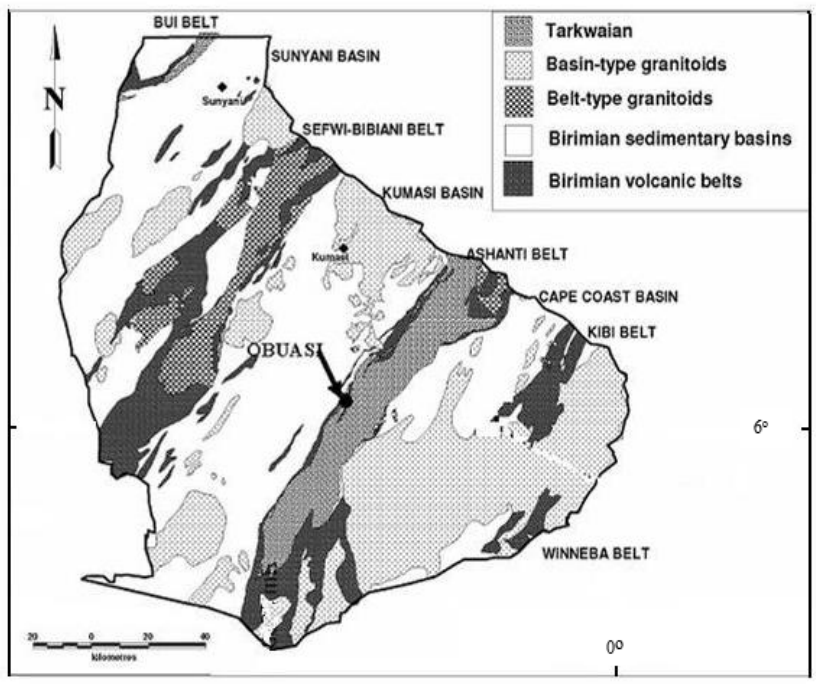

Fig 1: Map of southern Ghana showing major gold belts (modified after Kesse, 1985)

Resource evaluation diamond drill cores spatially distributed along strike length A-B (Fig 2) and a vertical height of $-1.6 \mathrm{~km}$ were sampled (Fig 3). The samples were all taken from the hardrock environment and so oxidation of the sulphide was therefore not anticipated. In all a total of 192 samples were taken and crushed to minus 400 mersh and tested concurrently for total sulphur and carbonate contents: also the large sample coverage and number was to minimize uncertainty in data quality, and also provide statistical basis to account for sample variability (BC AMD Task Force 1989; Ferguson and Morin 1991; US EPA 1994; Maest et al. 1995).

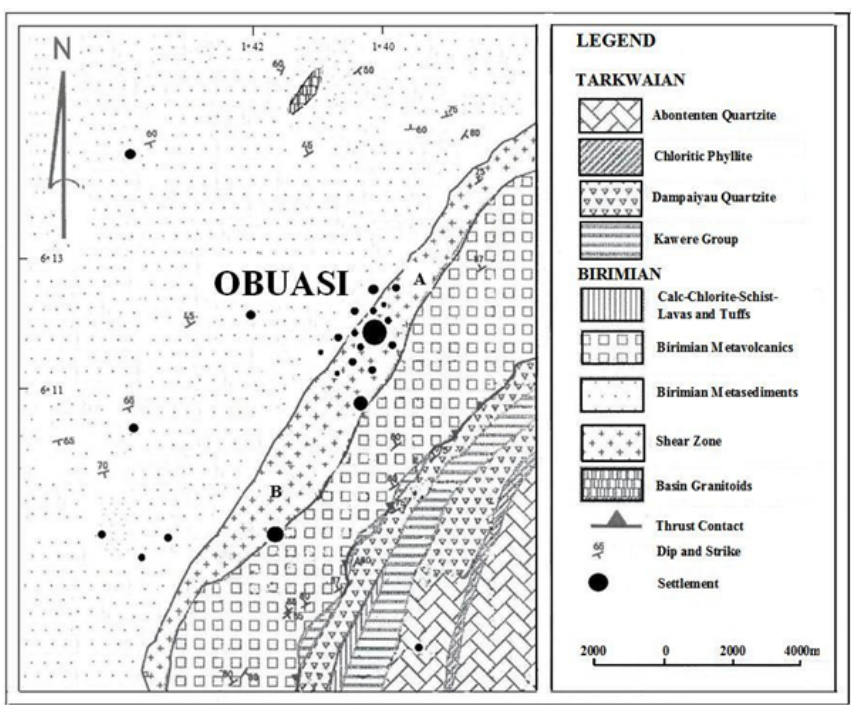

Fig 2: Geological map of the study area (modified after Kesse, 1985)

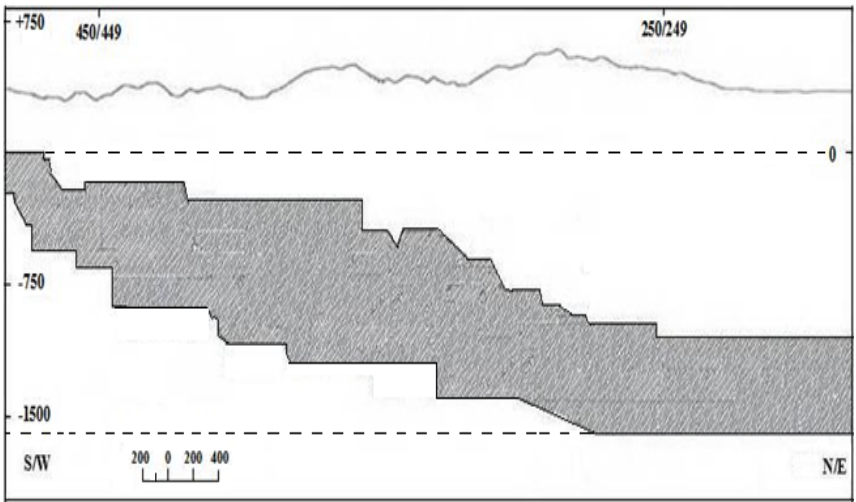

Fig 3: Vertical section of resource block outline

The experimental design was also influenced by the geological and geochemical characteristics of the deposit type, which suggests that common errors could easily be dealt with using unique mining methods and effective grade control practices.

\section{Data analysis}

Sulphur content determination: Total Sulphur determination was by high-temperature furnace 
combustion, using the LECO sulphur analyzer (LECO Corporation 2007). In the determination, $0.20 \mathrm{~g}$ of sample was decomposed to form $\mathrm{SO}_{2}$, primarily by the reactions;

$4 \mathrm{FeS}_{2}+11 \mathrm{O}_{2}===>2 \mathrm{Fe}_{2} \mathrm{O}_{3}+8 \mathrm{SO}_{4}$, and

$2 \mathrm{FeAsS}+6 \mathrm{O}_{2}+$ Heat $\left(1000^{\circ} \mathrm{C}\right)===>\mathrm{Fe}_{2} \mathrm{O}_{3}+$ $\mathrm{As}_{2} \mathrm{O}_{5}+2 \mathrm{SO}_{2}$

The $\mathrm{SO}_{2}$ formed was allowed to bubble through the hydrogen peroxide solution to form sulphuric acid $\left(\mathrm{H}_{2} \mathrm{SO}_{4}\right)$, in a reaction time of 10 minutes, e.g.;

$\mathrm{SO}_{2}+\mathrm{H}_{2} \mathrm{O}_{2}===>\mathrm{H}_{2} \mathrm{SO}_{4}$

The $\mathrm{H}_{2} \mathrm{SO}_{4}$ was titrated against $0.05 \mathrm{~N}$ Borax solution to a grayish-green colour end point.

$\mathrm{H}_{2} \mathrm{SO}_{4}+\mathrm{Na}_{2} \mathrm{~B}_{4} \mathrm{O}_{7}===>\mathrm{Na}_{2} \mathrm{SO}_{4}+\mathrm{H}_{2} \mathrm{~B}_{4} \mathrm{O}_{7}$

Total sulphur was then calculated in percentage by the relationship;

$\left(F^{*} V^{*} 100\right) \div M$; where, $M=$ mass of sample,

$\mathrm{F}=$ sodium tetraborate factor in terms of sulphur; and

$\mathrm{V}=$ volume of $\mathrm{Na}_{2} \mathrm{~B}_{4} \mathrm{O}_{7}$ solution used in the titration of the sample.

Carbonate content determination: The determination of the carbonate was carried out by decomposing $0.2 \mathrm{~g}$ of the carbonate sample with $2.0 \mathrm{~mL}$ of $6 \mathrm{M} \mathrm{HCl}$ (Pile et al. 1998) by the following reaction mechanism;

$2 \mathrm{HCl}_{(\mathrm{l})}+\mathrm{XCO}_{3(\mathrm{~s})}===>\mathrm{X}^{2+}{ }_{(\mathrm{aq})}+2 \mathrm{Cl}^{-}{ }_{(\mathrm{aq})}+\mathrm{H}_{2} \mathrm{O}_{(\mathrm{l})}+\mathrm{CO}_{2(\mathrm{~g})}$

The carbon dioxide evolved was absorbed in $2 \mathrm{M}$ soda lime $(\mathrm{NaOH})$ solution as follows;

$2 \mathrm{NaOH}_{(\mathrm{aq})}+\mathrm{CO}_{2(\mathrm{~g})} \quad===>\quad \mathrm{NaCO}_{3(\mathrm{~s})}+\mathrm{H}_{2} \mathrm{O}_{(\mathrm{l})}$

The increase in weight of the absorbent was determined and used for the calculation of the amount of $\mathrm{CO}_{2}$ in the sample (Vogel 1989). To ensure accuracy of the value of $\mathrm{CO}_{2}$ absorbed, the $\mathrm{NaOH}$ was used in excess and the filtrate of the $\mathrm{NaCO}_{3}$ solution was titrated with $0.5 \mathrm{M} \mathrm{HCl}$. The titration data was used to estimate the amount of $\mathrm{CO}_{2}$ absorbed and used as a check.

Data evaluation: Acid generation potential which is commonly referred to as maximum potential acidity (MPA) is based on the percentage sulphur content in ores, while neutralisation potential (NP) is due to the presence of carbonate minerals and mostly in the form of calcite (Williams et al. 1982; Perry 1985). The balance between the NP and MPA is referred to as Net Neutralisation Potential (NNP), and related by;

NNP = NP - MPA, where MPA is computed as $\%$ Total $S^{\star} 31.25$, and the constant, 31.25 defined as
$31.25 \mathrm{Mg}$ of $\mathrm{CaCO}_{3}$ or $\mathrm{kg} \mathrm{CaCO}_{3} /$ ton. The $31.25 \mathrm{Mg}$ of $\mathrm{CaCO}_{3}$ will be required to neutralize $1000 \mathrm{Mg}$ of rock containing $1 \%$ pyritic $S$ in open systems. The process assumes that acid generation and neutralization takes place concurrently; sulphides are the only source of acid generation; there is complete oxidation of pyrite; and finally all generated acids are neutralized (Perry 1985, Ferguson and Morin 1991; Joseph et al. 1994).

\section{RESULTS AND DISCUSSION}

Control charts to determine data variability in primary data within $\pm 3 \sigma$ level of the mean had six (6) from 92 samples violating the rule for total sulphur determination (Fig 4), while one (1) from 92 samples violated the rule for carbonate determination (Fig 5). Average carbonate (NP) value was $4.34 \mathrm{~kg}$ $\mathrm{CaCO}_{3}$ /ton while percentage total sulphur content was also $1.46 \%$, and resulted in MPA value of 45.63 $\mathrm{kg} \mathrm{CaCO}_{3} /$ ton. Figure 6 presents the spatial distribution of the neutralization model plot for NP versus MPA (Downing 2010). From the multiple regression statistics to test the neutralization-acidity of the model, the quantities had a low R-square value of 0.0005 for the individual samples. The closeness of the R-square value to zero $(0)$ indicated an overall weak predictive accuracy of the neutralization model. $\mathrm{R}$-square closer to one (1) would have suggested a stronger predictive model. NNP and NP/MPA values were -41.29 and 0.095 respectively. The low Rsquare value confirmed the wide variation between the neutralization potential and the acid generation capacity of the test material.

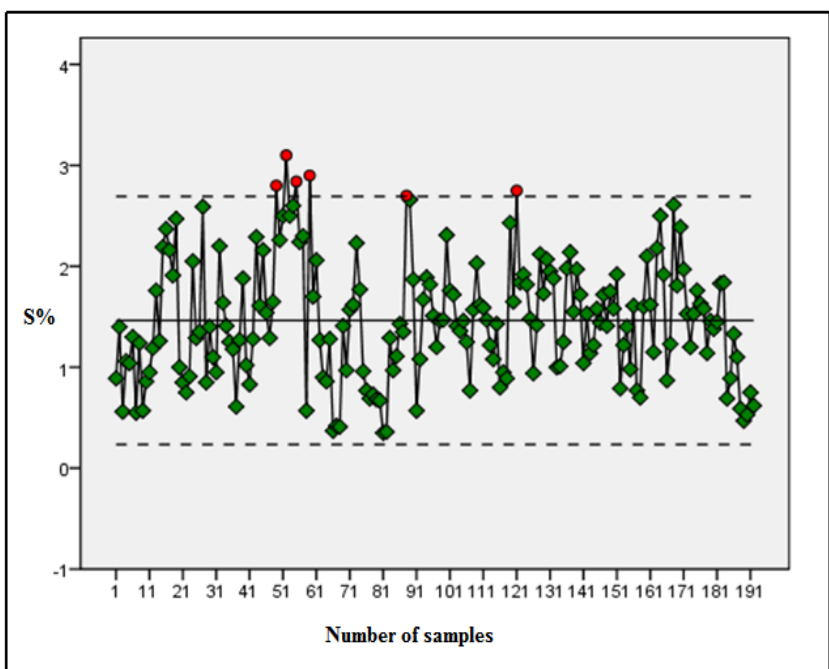

Fig 4: Control chart for sulphur analysis 


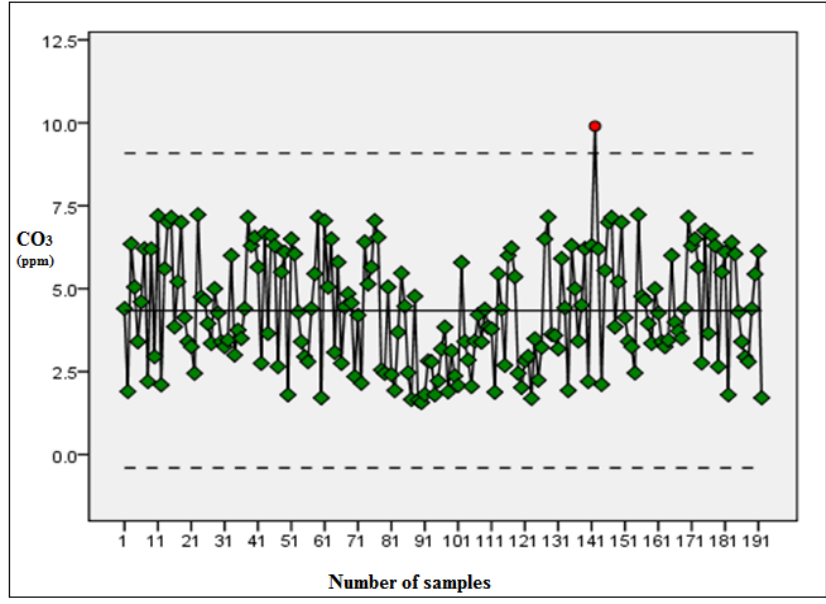

Fig 5: Control chart for $\mathrm{CO}_{3}$ analysis

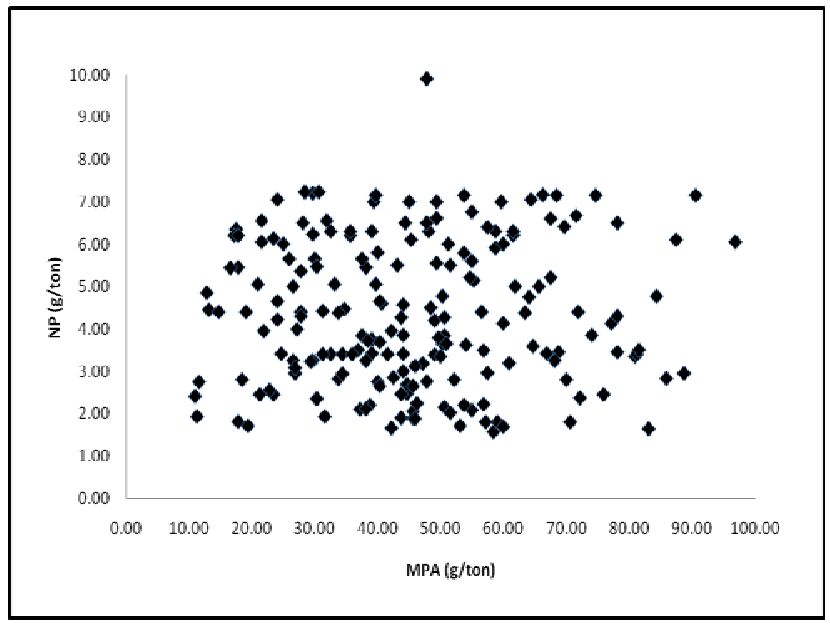

Fig 6: Neutralization plot for NP versus MPA

The Net Neutralisation Potential (NNP) value of $-41.29 \mathrm{~kg} \mathrm{CaCO} /$ tons is less than the minimum value of $-20 \mathrm{~kg} \mathrm{CaCO} /$ ton and equates to NP/MPA ratio of 0.095 which is also less than 1 . On the contrary, NNP value greater than $20 \mathrm{~kg} \mathrm{CaCO} /$ /ton or NP/MPA ratio $>3$ will imply that the material may produce alkaline drainage, or has a low risk of acid formation (BC AMD Task Force 1989; Ferguson and Morin 1991). Between these extremes, AMD potentiality is critical or uncertain, and can only be further determined by kinetic method. For NP=MPA; NNP=0; and NP/MPA $=1$ indicates a perfect balance or absolute neutrality (Smith and Barton Bridges 1991).

Results from the study therefore implied that tailings waste material from the sulphide ores will generate highly acidic waters if no remediation plan is implemented. From literature, the uncertainty is a factor between particle sizes; since the test media is anticipated to be similar in particle size to the tailings waste to be generated from milling of ores, results in both field and experimental data are expected to follow the same trend. Particle size will therefore not be a challenge to the prediction of water quality. In addition, the different geological and geochemical characteristics associated with the sulphide ores as compared with the conventional coal mine deposit types that are synonymous with ABA procedure can help reduce errors in data. Another key aspect that can help minimize errors is the unique applicable mining methods and grade control practices that is used to partition potential sulphide material in the hardrock environment for treatment. The observed acid generation potential of test material are confirmed in earlier work by Akabzaa et al. (2007), where both net acid generation (NAG) $\mathrm{pH}$ and $A B A$ results were found to be consistent with tailings at mine sites located on the same gold belt and south of the area. Based on the above assertion, alkaline amendment requiring an amount of $21.29 \mathrm{~kg}$ $\mathrm{CaCO}_{3} /$ ton to $61.29 \mathrm{~kg} \mathrm{CaCO}_{3} /$ ton is needed to be blend with ores during treatment in order to ensure that the NNP balance range of -20 to 20 is maintained. On the other hand a value of $41.29 \mathrm{~kg}$ $\mathrm{CaCO}_{3} /$ ton is required to ensure absolute neutrality.

\section{CONCLUSION:}

The ABA procedure, despite often plagued with many uncertainties can be relied upon as a key predictive tool for evaluating sulhpide gold ores along the Ashanti metallogenic belt. Results are perceived as reliable due to the effective mining practices to minimize ore loss, and also ore pre-treatment methods to minimize overestimation of ABA data in test material. The test media, as anticipated for tailings waste is expected to promote good acid neutralization programs involving carbonates during ore beneficiation. Further testing of materials to confirm the ABA procedure may become irrelevant as the MPA value far outweighs the NP value as observed in this study. Empirical data so generated can be used in the design and cost remediation plans that will enable compliance with water quality standards in a more technical, economical and an efficient manner. Results can also be used for making informed, realistic and appropriate decisions during project feasibilities at the exploratory stage of mining projects.

\section{ACKNOWLEDGEMENT}

Acknowledgements go to all those who in diverse ways helped to make this research a success. 


\section{REFERENCES}

Akabzaa, T (2000). Boom and Dislocation: The Environmental and Social Impacts of Mining in the Wassa West District of Ghana. Accra, Ghana: Third World Network. 131p.

Akabzaa, T.M., Armah, T.E.K and Baneong-Yakubo, B.K (2007). Prediction of acid mine drainage generation potential in selected mines in the Ashanti Metallogenic Belt using static geochemical methods. Environ Geol (2007) 52:957-964

Brady, K., Smith M.W., Beam, R.L and Cravotta, C.A (1990). Effectiveness of the use of alkaline materials at surface coal mines in preventing or abating acid mine drainage: Part 2. Mine site case studies. p. 227-241. In: Proceedings, 1990 Mining and Reclamation Conference, April 23-26, 1990, West Virginia University, Morgantown, WV

BC AMD Task Force (1989). Draft Acid Rock Drainage Technical Guide, Volume 1, British Columbia Acid Mine Drainage Task Force Report prepared by Steffen Robertson and Kirsten, Norelco Environmental Consultants, and Gormely Process Engineering, August 1989

da Rosa, D and Lyon, J.S (1997). Golden Dreams, Poisoned Streams, Part 1; Mineral Policy Centre, Washington D.C, 1997, p.64-68

Downing, B.W (2010). The Management of Analysis of ARD Data;

http://technology.infomine.com/enviromine/ard/Case \% 20Studies/data.html (Accessed 11-09-2010)

Ferguson, K. D and Morin, K.A (1991). The Prediction of Acid Rock Drainage - Lessons from the Database; In Second International Conference on the Abatement of Acidic Drainage; Conference Proceedings, Volumes 14, September 16, 17, and 18, 1991, Montreal, Canada

Gautama, R.S and Hartaji, S (2004). Improving the Accuracy of Geochemical Rock Modelling for Acid Rock Drainage Prevention in Coal Mine, Journal of the International Mine Water Association, Vol. 23, Number 2, August 2004

Hamric, R., Miller, V and Skousen, J (2001). In: Proceedings, Sixteenth Annual Surface Mine Drainage Task Force...

wvmdtaskforce.com/proceedings/01/HAMRIC.PDF (Accessed on 31-08-2010)

Hamrin, H (1986). Underground mining methods and application; Chapter 1 (Guide to underground mining methods and applications [3rd ed.] Published by Atlas Copco in Stockholm, Sweden) www.ct.ufrgs.br/laprom/Underground\%20Mining\%20M ethods.pdf (Accessed 10-09-2010)
Hirdes, W., Davis, D. W and Eisenlohr, B. N (1992). Reassessment of Proterozoic granitoids ages in Ghana on the basis of $\mathrm{U} / \mathrm{Pb}$ zircon and monzonite dating. Precambrian Research 56, 89-96.

Jennings, S.R., Neuman, D.R and Blicker, P.S (2008). "Acid Mine Drainage and Effects on Fish Health and Ecology: A Review". Reclamation Research Group Publication, Bozeman, MT

Joseph, W.L., Brady, K.B.C and Perry, E.F (1994). Variation in computing acid base accounting in the U.S. Abstract In: International Land Reclamation and Mine Drainage Conference and Third International Conference on the Abatement of Acidic Drainage, $U$. S. Bureau of Mines Special Publication SP 06B-94, p. 417.

Kesse, G.O (1985). Rock and Mineral Resources of Ghana- A.A Balkema/Rotterdam/Boston. p.11-35

Kempton, H (2002). Dealing with the legacy of mine pit lakes. Southwest Hydrology, Vol 1 \#3, pg. 24-26.

Kuipers, J.R., Maest, A.S., MacHardy, K.A and Lawson, G (2006). "Comparison of Predicted and Actual Water Quality at Hardrock Mines: The reliability of predictions in Environmental Impact Statements." Kuipers \& Associates, PO Box 641, Butte, MT USA 5970. p228

LECO Corporation (2007). 3000 Lakeview Ave. St. Joseph, MI 49085, info@leco.com, www.l, eco.com, ISO9001:2000 No. FM 24045, p 3-12

Leube, A., Hirdes, W., Mauer, R and Kesse, G.O (1990). The Early Proterozoic Birimian Supergroup of Ghana and some aspects of its associated gold mineralisation. Precambrian research 46, 139-165.

Maest, A.S., Kuipers, J.R., Travers, C.L and Atkins, D.A (2005). Predicting Water Quality at Hardrock Mines:Methods and Models, Uncertainties, and Stateof-the-Art.

McKenna, N., Taylor, R.M and Clay, A.N (2009). Preliminary, Desktop, Scoping study on The Tulu Kapi Gold Project, Ethiopia; Nyota Minerals Limited (Nyota)

MEND (2001). "List of Potential Information Requirements in Metal Leaching/ Acid Rock Drainage Assessment and Mitigation Work". Mining Environment Neutral Drainage Program. W. A. Price, CANMET, Canada Centre for Mineral and Energy Technology.

Osae, S., Kase, K and Yamamoto, M (1995). A geochemical study of the Ashanti gold deposit at Obuasi, Ghana. Department of Earth Sciences, Faculty of Science, OKAYAMA University; Earth Science Reports, 2, (1), 81-90.

Perry, E.F (1985). Overburden analysis: An evaluation of methods; p. 369-375. In Proc. Symp. of Surface Mining, Hydrology, Sedimentology, and Reclamation, Lexington, KY. 9-13 Dec. 1985, OSC, p. 12. 
Perry, E.F and Brady, K.B (1995). Influence of neutralization potential on surface mine drainage quality in Pennsylvania. In: Proceedings, Sixteenth Annual Surface Mine Drainage Task Force Symposium, April 4-5, 1995, Morgantown, WV.

Pile, D.L., Benjamin, A.S., Lackner, K.S., Wendt, C.H and Butt, D.P (1998). A precise Methos for Determining the $\mathrm{CO}_{2}$ Content in Carbonate Materials. Journal of Chemical Education.

Rich, D.H and Hutchison, K.R (1990). Neutralization and stabilization of combined refuse using lime kiln dust at High Power Mountain. p. 55-60. In: Proceedings, 1990 Mining and Reclamation Conference. West Virginia University.

Rose, A.W., Phelps, L.B., Parizek, R.R and Evans, D.R (1995). Effectiveness of lime kiln flue dust in preventing acid mine drainage at the Kauffman surface coal mine, Clearfield County, Pennsylvania. p. 159171. In: Proceedings, $12^{\text {th }}$ American Society for Surface Mining and Reclamation Conference, Gillette, WY.

Runkel, R.L., Kimball, B.A., Walton-Day K and Verplanck, P.L (2007). A simulation-based approach for estimating premining water quality: Red 'Mountain Creek, Colorado Applied Geochemistry 22 (2007) 1899-1918

Rymer, T.E., Renton J.J and Ziemkiewicz P.F (1991). Isolation of critical predictive acidproducing parameters from variable field data using advanced computer technology. In: Proceedings, $2^{\text {nd }}$ International Conference on the Abatement of Acidic Drainage, September 16- 18, 1991, MEND, CANMET, Montreal, Canada.

Saharan, M.R., Gupta, K.K., Jamal, A and Sheoran, A.S (1995). Management of acidic effluents from tailing dams in metalliferous mines Mine water and the environment, vol. 14, annual issue, paper 7, pp 85-94

Sanderson, M.R (2009). Globalization and the Environment: Implications for Human Migration. Human Ecology Review, Vol. 16, No. 1

Scharer, J.M., Bolduc, L., Pettit, C.M and Halbert, B.E. (2000). "Limitations of Acid-base Accounting for Predicting Acid Rock Drainage"; 5th International Conference on Acid Rock Drainage, Denver, CO, Society for Mining, Metallurgy and Exploration.

Smith, A and Barton Bridges, J.B (1991). Some Considerations in the Prediction and Control of Acid Mine Drainage Impact on Groundwater From Mining in North America. In: Proceeding of the EPPIC Water Symposium, Johannesburg.
Singh, R and Singh, B.P (1992). Environmental Pollution by Mill tailings and Control Methods, Ind. Journal of Environmental protection, Vol. 12, No. 5 pp 329-334

Skousen, J., Simmons, J., McDonald, L.M and Ziemkiewicz, P (2002). Acid-Base Accounting to Predict Post-Mining Drainage Quality on Surface Mines Published in J. Environ. Qual. 31:2034-2044 (2002)

Skousen, J.G and Ziemkiewicz, P.F (1996). "Acid Mine Drainage Control and Treatment." Second Edition. Morgantown, W.V., West Virginia University and the National Mine Land Reclamation Center.

Sobek, A., Schuller, W., Freeman, J.R and Smith, R.M (1978). Field and Laboratory Methods Applicable to Overburdens and Minesoils. Prepared for U.S. Environmental Protection Agency, Cincinnati, Ohio: EPA-600/2-78-054, $203 p$

Stromberg, B and Banwart, S.A (1999). Experimental study of acidity-consuming processes in mining waste rock: some influences of mineralogy and particle size. Applied Geochemistry Vol. 14: 1-16

Taylor, P. N., Moorbath, S., Leube, A and Hirdes, W (1992). Early Proterozoic crustal evolution in the Birimian of Ghana; constraints from geochronology and isotope geology. Precambrian research 56, 77111.

US EPA (1994). Acid Mine Drainage Prediction. Technical Document. U.S. Environmental Protection Agency, Office of Solid Waste Special Waste Branch, EPA530R-94-036, NTIS PB94-201829. 48pp

Vogel's Textbook of Quantitative chemical analysis (1989). Eds. Jeffery CH, Bassett J, Mendham J, Denny RC; $5^{\text {th }}$ Edition. Bash Press Ltd. UK, pp 477-479.

White, W.W., Lapakko, K.A and Cox, R.L (1999). Static-test methods most commonly used to predict acid-mine drainage: Practical guidelines for use and interpretation. In: Reviews in Economic Geology, Volume 6A. The Environmental Geochemistry of Mineral Deposits. Part A: Processes, Techniques, and Health Issues. Plumlee, G.S. and Logsdon, M.J., eds. P. 325-338.

Williams, E.G., Rose, A.W., Parizek R.R and Waters, S.A (1982). Factors controlling the generation of acid mine drainage. The Pennsylvania State University final report to the U. S. Bureau of Mines, Grant G5105086, $256 \mathrm{p}$.

Wiram, V.P and Naumann, H.E (1995). Alkaline additions to the backfill: A key mining/reclamation component to acid mine drainage prevention. In: Proceedings, Sixteenth Annual Surface Mine Drainage Task Force Symposium, April 4-5, 1995, Morgantown, WV. 